\title{
Transdiaphragmatic Resuscitative Open Cardiac Massage: Description of the Technique and a First Case-Series of an Alternative Approach to the Heart
}

\author{
Beat Schnüriger - Peter Studer - Daniel Candinas • \\ Christian A. Seiler
}

Published online: 6 January 2014

(C) Société Internationale de Chirurgie 2014

\begin{abstract}
Background The purpose of this paper is to describe the transdiaphragmatic approach to the heart for open CPR in patients that arrest at laparotomy and to present a first case series of patients that have undergone this procedure.

Methods All patients who had undergone intraperitoneal transdiaphragmatic open CPR between January 1, 2002 and December 31, 2012 were retrieved from the operation registry at Bern University Hospital, Switzerland. Transdiaphragmatic access to the heart is initiated with a 10-cm-long anterocaudal incision in the central tendon of the diaphragm-approximately at 2 o'clock. Internal cardiac compression through the diaphragmatic incision can be performed from both sides of the patient. From the right side of the patient, cardiac massage is performed with the right hand and vice versa.

Results A total of six patients were identified that suffered cardiac arrest during laparotomy with open CPR performed through the transdiaphragmatic approach. Four patients suffered cardiac arrest during orthotopic liver transplantation and two trauma patients suffered cardiac arrest during damage control laparotomy. In three patients, cardiac activity was never reestablished. However, three patients regained a perfusion heart rhythm and two of these survived to the ICU. One patient ultimately survived to discharge.

Conclusions In patients suffering cardiac arrest during laparotomy, the transdiaphragmatic approach allows for a
\end{abstract}

Presented at the 1st Annual Swiss Trauma \& Resuscitation Day, February 23, 2012, Bern, Switzerland and at the 14th European Congress of Trauma \& Emergency Surgery, May 5, 2013 Lyon, France.

B. Schnüriger · P. Studer · D. Candinas · C. A. Seiler $(\square)$ Department of Visceral and Transplant Surgery, Bern University Hospital, 3010 Bern, Switzerland

e-mail: christian.a.seiler@insel.ch rapid, technically easy, and almost atraumatic access to the heart, with excellent CPR performance. After this potentially life-saving procedure, pulmonary or surgical site complications are expected to occur much less compared with the conventionally performed emergency department left-sided thoracotomy.

\section{Introduction}

Open cardiopulmonary resuscitation (CPR) was first described and applied in the 1960s [1-3]. For trauma patients who require CPR after suffering cardiac arrest, emergency department resuscitative thoracotomy (EDT) gives the best survival rates if performed in the emergency department (ER) or operating room (OR) [4-7]. If the cardiac arrest has been witnessed, EDT is recommended for patients with both blunt or penetrating injuries [4]. EDT is conventionally performed through a standard left-sided thoracic incision in the fourth intercostal space.

However, in patients who suffer cardiac arrest during laparotomy, the intraperitoneal transdiaphragmatic access to the heart may be a less traumatic technique to achieve effective open CPR. A review of the literature found only a single case report of transdiaphragmatic cardiac resuscitation through a midline abdominal incision [8]. We present six additional cases and describe our technique for this alternative approach to the heart in patients suffering cardiac arrest for different reasons during laparotomy.

\section{Methods}

All patients who had undergone intraperitoneal transdiaphragmatic open CPR between January 1, 2002 and 
December 31, 2012 were retrieved from the operation registry at Bern University Hospital, a Level-I Trauma and Transplant Center in Switzerland. Patients' charts, OR, and anesthesiology reports were queried and basic demographics were retrospectively recorded.

At Bern University Hospital, the transdiaphragmatic access to the heart was performed for the first time in 2002. Since then, six patients suffering cardiac arrest during elective or emergent laparotomy without evidence of additional thoracic injuries have undergone intraperitoneal transdiaphragmatic open CPR. In addition, electric conversion and administration of resuscitative drugs are applied according to the European Resuscitation Council guidelines for resuscitation [9]. In cases of prolonged cardiopulmonary failure, an extracorporeal membrane oxygenation (ECMO) device may be applied at the discretion of the attending surgeon. Patients who regain cardiac rhythm with stabilized hemodynamics are transferred immediately to the intensive care unit (ICU), where they are treated further by both the surgical and the ICU team.

Transdiaphragmatic access to the heart is initiated with a 10 -cm-long anterocaudal incision in the central tendon of the diaphragm-approximately at 2 o'clock (Fig. 1). The pericardium is easily opened, as the medial portion of the diaphragm is attached to it. Pericardial tamponade is excluded and the descending aorta may be clamped just below the diaphragm. Internal cardiac compression through the diaphragmatic incision can be performed from both sides of the patient. From the right side of the patient, cardiac massage is performed with the right hand and vice versa. With the hand and wrist in a comfortable position, the extended fingers of the right hand are placed over the lateral aspect of the left ventricle, the thenar eminence, and thumb over the right ventricle (Fig. 2). After finishing manual cardiac compressions, the anterior and lateral branches of the phrenic artery are ligated and the diaphragm is closed by a running nonabsorbable suture. As long as the pleural cavity remains intact, no chest drain is placed.

\section{Results}

During the past 10 years at Bern University Hospital, a total of six patients were identified that suffered cardiac arrest during laparotomy with open CPR performed through the transdiaphragmatic approach, as described above. Table 1 shows a summary of the characteristics of these six patients.

The six patients included in this case series comprised four patients who suffered cardiac arrest during orthotopic liver transplantation (OLT) and two trauma patients who suffered cardiac arrest during damage control laparotomy.

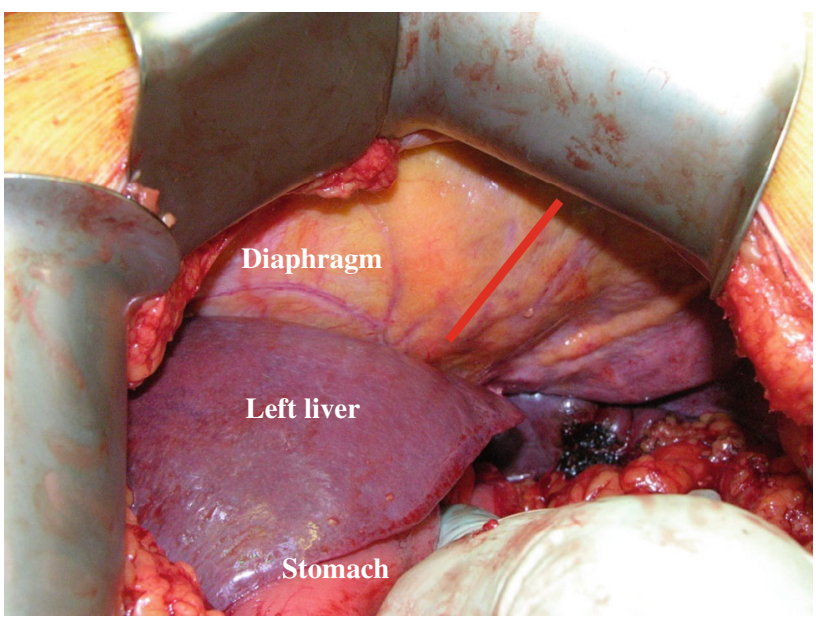

Fig. 1 Intraperitoneal transdiaphragmatic access to the heart: location of the incision (red line)

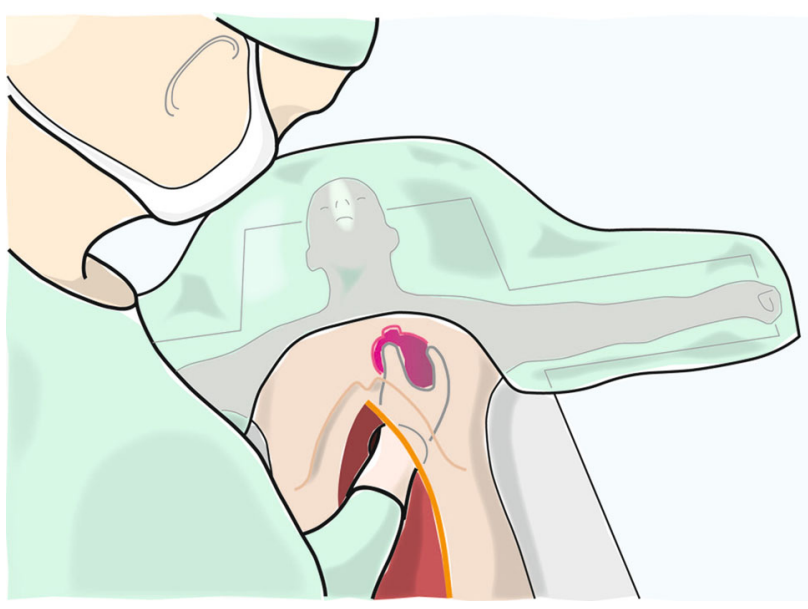

Fig. 2 Performing transdiaphragmatic open cardiac massage from the right side

The overall mean duration of cardiac massage was $36 \pm 17 \mathrm{~min}$. There were no complications or morbidity related to the transdiaphragmatic approach to the heart. The pleural cavities were never accidentally opened. As adjuncts to manual cardiac compressions, electric defibrillation was applied in two patients, and extracorporeal circulation devices (ECMO) were installed in another two patients.

In three patients, cardiac activity was never reestablished. However, three patients regained a perfusion heart rhythm and two of these survived to the ICU. One patient ultimately survived to discharge. This was a 44-year-old male patient who had suffered cardiac arrest during OLT. This patient arrested during the initial phase of liver reperfusion. In this patient, $29 \mathrm{~min}$ of transdiaphragmatic cardiac massage was performed. After reestablishing a perfusing heart rhythm, an ECMO was placed to support 
Table 1 Characteristics of patients suffering cardiac arrest during laparotomy, followed by transdiaphragmatic access to the heart for open CPR

\begin{tabular}{|c|c|c|c|c|c|c|c|c|c|c|}
\hline Gender & $\begin{array}{l}\text { Age } \\
\text { (year) }\end{array}$ & Diagnosis & $\begin{array}{l}\text { Surgical } \\
\text { procedure }\end{array}$ & PRBC & FFP & The & $\begin{array}{l}\text { Duration of open } \\
\text { cardiac massage } \\
\text { (min) }\end{array}$ & $\begin{array}{l}\text { Adjuncts to } \\
\text { resuscitation }\end{array}$ & HLOS & Outcome \\
\hline Male & 44 & $\begin{array}{c}\text { Liver cirrhosis } \\
\text { (hepatitis C) }\end{array}$ & OLT & 40 & 40 & 3 & 29 & ECMO & 137 & Survived \\
\hline Male & 6 & $\begin{array}{l}\text { MVA (motorcycle } \\
\text { vs. car) liver } \\
\text { laceration }{ }^{\circ} \mathrm{V}\end{array}$ & $\begin{array}{l}\text { Damage control } \\
\text { laparotomy }\end{array}$ & 26 & 22 & 5 & 60 & ECMO & 1 & $\begin{array}{l}\text { Survived } \\
\text { to ICU }\end{array}$ \\
\hline Male & 63 & $\begin{array}{l}\text { Liver cirrhosis } \\
\text { (Alpha-1 AT } \\
\text { deficiency) }\end{array}$ & OLT & 15 & 27 & 0 & 37 & Defibrillation & 0 & $\begin{array}{l}\text { Intermitted } \\
\text { cardiac } \\
\text { activity }\end{array}$ \\
\hline Male & 20 & $\begin{array}{l}\text { MVA } \\
\text { retroperitoneal } \\
\text { bleeding }\end{array}$ & $\begin{array}{l}\text { Damage control } \\
\text { laparotomy }\end{array}$ & 11 & 10 & 1 & 20 & no & 0 & $\begin{array}{c}\text { No cardiac } \\
\text { activity }\end{array}$ \\
\hline Male & 67 & $\begin{array}{l}\text { Liver cirrhosis } \\
\text { (NASH) }\end{array}$ & OLT & 7 & 20 & 0 & 40 & Defibrillation & 0 & $\begin{array}{c}\text { No cardiac } \\
\text { activity }\end{array}$ \\
\hline Female & 64 & $\begin{array}{l}\text { Hepatic } \\
\text { echinococcus } \\
\text { multilocularis }\end{array}$ & Re-OLT & 5 & 12 & 1 & 30 & no & 0 & $\begin{array}{c}\text { No cardiac } \\
\text { activity }\end{array}$ \\
\hline
\end{tabular}

$P R B C$ packed red blood cells, $F F P$ fresh frozen plasma, Thc pooled platelet concentrates, $M V A$ motor vehicle accident, $E C M O$ extracorporeal membrane oxygenation, ICU intensive care unit, $N A S H$ nonalcoholic steatohepatitis, $O L T$ orthotopic liver transplantation, $A T$ antitrypsin

the diminished cardiac function. The patient was discharged on hospital day 137 . He fully recovered and is working again with normal neurological function.

Both of the two trauma patients included in this case series suffered blunt trauma due to motor vehicle accidents, with cardiac arrest during damage control laparotomy. One was a 6-year-old male patient who suffered an isolated grade $\mathrm{V}$ liver laceration with involvement of the retrohepatic vena cava. This patient suffered arrest at laparotomy, and the heart was immediately accessed through the transdiaphragmatic approach. After $60 \mathrm{~min}$ of cardiac massage, massive transfusion and installation of an ECMO, the patient regained a perfusing heart rhythm and was transferred to the ICU. However, this patient expired at day 1 after the accident due to cardiopulmonary collapse.

\section{Discussion}

In patients suffering cardiac arrest during laparotomy without evidence of thoracic injuries, the transdiaphragmatic approach to the heart is a valuable alternative to the conventional access through the standard left-sided thoracic incision at the fourth intercostal space. As shown in the current case series, cardiac massage and, if needed, aortic clamping or electric conversion can be performed adequately in this alternative technique.

Since its first description in the 1960s [1-3], the role of open CPR in the resuscitation of injured patients has remained controversial, due to the overall poor outcome of these patients. Some investigators have proposed that EDT is futile care and a waste of resources, while proponents advocate the use of this life-saving procedure in selected cases [5, 6, 10-17]. Especially in cases with a witnessed cardiac arrest, open CPR is recommended-conventionally through a left-sided thoracotomy [4].

According to our experience, in patients suffering cardiac arrest with the peritoneal cavity already open, the surgical procedure of transdiaphragmatic access to the heart is easy, safe, and performed within less than a minute. This surgical technique, as described here, is similar to the transdiaphragmatic or subxyphoidal diagnostic pericardial window, but the incision is lengthened to fit the hand of the surgeon [18]. With three of six patients with transient regain of a perfusing heart rhythm and one survivor, the outcome of this alternative technique is comparable to the conventionally performed EDT through a left-sided thoracotomy [7]. However, this alternative access to the heart adds a minimum of additional trauma to the patient compared to a left-sided thoracotomy. In none of the cases presented here, was the pleural cavity accidentally opened. Without the additional thoracic surgical trauma, pulmonary complications are expected to be much less.

In patients undergoing laparotomy for OLT, hyperkalemia in the reperfusion phase can cause cardiac arrhythmia or even cardiac arrest, which happened in four of the six patients included in the current series. After revascularization of the transplanted liver, washout of preservation fluid containing high concentrations of potassium may cause immediate postreperfusion hyperkalemia [19, 20]. In addition, reperfusion injury contributes to the dangerous hyperkalemia in these patients. Although pathophysiologically 
different, similar electrolyte changes, including severe hyperkalemia, were observed in trauma patients undergoing resuscitative EDT [7]. Therefore, the lessons learned from patients suffering cardiac arrest during OLT may be applied to trauma patients that arrest during damage control laparotomy.

\section{Conclusions}

In patients suffering cardiac arrest during laparotomy, the transdiaphragmatic approach allows for a rapid, technically easy, and almost atraumatic access to the heart, with excellent CPR performance. This potentially life-saving procedure adds minimal additional surgical trauma to the patient. After this alternative approach to the heart, pulmonary or surgical site complications are expected to occur much less compared to conventional EDT.

Conflict of interest None of the authors has any potential or real conflicts of interest that could inappropriately influence (bias) their work.

\section{References}

1. Briggs BD, Sheldon DB, Beecher HK (1956) Cardiac arrest; study of a thirty-year period of operating room deaths at Massachusetts General Hospital, 1925-1954. J Am Med Assoc 160:1439-1444

2. Delguercio LR, Feins NR, Cohn JD et al (1965) Comparison of blood flow during external and internal cardiac massage in man. Circulation 31(Suppl 1):171-180

3. Turk LN 3rd, Glenn WW (1954) Cardiac arrest; results of attempted cardiac resuscitation in 42 cases. N Engl J Med 251:795-803

4. Working Group, Ad Hoc Subcommittee on Outcomes, American College of Surgeons-Committee on Trauma (2001) Practice management guidelines for emergency department thoracotomy. J Am Coll Surg 193:303-309

5. Martin SK, Shatney CH, Sherck JP et al (2002) Blunt trauma patients with prehospital pulseless electrical activity (PEA): poor ending assured. J Trauma 53:876-880 (discussion 880-871)
6. Rhee PM, Acosta J, Bridgeman A et al (2000) Survival after emergency department thoracotomy: review of published data from the past 25 years. J Am Coll Surg 190:288-298

7. Schnuriger B, Talving $P$, Inaba K et al (2012) Biochemical profile and outcomes in trauma patients subjected to open cardiopulmonary resuscitation: a prospective observational pilot study. World J Surg 36:1772-1778. doi:10.1007/s00268-012-1583-3

8. Suresh Kumar S, Saith V, Chawla R et al (2001) Successful transdiaphragmatic cardiac resuscitation through midline abdominal incision in patient with flail chest. Resuscitation 50:239-241

9. Deakin CD, Nolan JP, Soar J et al (2010) European resuscitation council guidelines for resuscitation 2010 section 4. Adult advanced life support. Resuscitation 81:1305-1352

10. Rosemurgy AS, Norris PA, Olson SM et al (1993) Prehospital traumatic cardiac arrest: the cost of futility. J Trauma 35:468-473 (discussion 473-464)

11. Powell DW, Moore EE, Cothren CC et al (2004) Is emergency department resuscitative thoracotomy futile care for the critically injured patient requiring prehospital cardiopulmonary resuscitation? J Am Coll Surg 199:211-215

12. Sheppard FR, Cothren CC, Moore EE et al (2006) Emergency department resuscitative thoracotomy for nontorso injuries. Surgery 139:574-576

13. Fialka C, Sebok C, Kemetzhofer P et al (2004) Open-chest cardiopulmonary resuscitation after cardiac arrest in cases of blunt chest or abdominal trauma: a consecutive series of 38 cases. J Trauma 57:809-814

14. Demetriades D, Rabinowitz B, Sofianos C (1987) Emergency room thoracotomy for stab wounds to the chest and neck. J Trauma 27:483-485

15. Ivatury RR, Kazigo J, Rohman M et al (1991) "Directed" emergency room thoracotomy: a prognostic prerequisite for survival. J Trauma 31:1076-1081 (discussion 1081-1082)

16. Schnuriger B, Inaba K, Branco BC et al (2010) Organ donation: an important outcome after resuscitative thoracotomy. J Am Coll Surg 211:450-455

17. Lustenberger T, Labler L, Stover JF et al (2012) Resuscitative emergency thoracotomy in a Swiss trauma centre. Br J Surg 99:541-548

18. Asensio JA, Stewart BM, Murray J et al (1996) Penetrating cardiac injuries. Surg Clin N Am 76:685-724

19. Homvises B, Sirivatanauksorn Y, Limsrichamrern S et al (2008) The minimal flush volume for washout of preservation fluid in liver transplantation. Transplant Proc 40:2123-2126

20. Shi XY, Xu ZD, Xu HT et al (2006) Cardiac arrest after graft reperfusion during liver transplantation. Hepatobiliary Pancreat Dis Int 5:185-189 